\title{
MENINGKATKAN KEMAMPUAN BERBICARA PADA PELAJARAN \\ BAHASA INDONESIA DENGAN MENGGUNAKAN METODE SOSIODRAMA SISWA KELAS V SD NEGERI 104214 \\ DELI TUA
}

\author{
Erlinda Simanungkalit \\ Surel: istarisyaira@gmail.com
}

\begin{abstract}
The purpose of this study is to improve students' speaking ability by applying the sociodrama method through learning Indonesian in grade V SD Negeri 104214 Deli Tua. This type of research is collaborative action research (PTK). Data collection methods used are observation, and documentation. Based on observation result of first ability of researcher with teacher of class 38 people from 26 students there are 5 students who able to speak with percentage $(13,1 \%)$ and 33 students who have not able to speak with percentage (86,9\%), with mean value Class 23.68 .
\end{abstract}

Keywords: Ability, Speaking, Sociodrama

\begin{abstract}
ABSTRAK
Tujuan penelitian ini adalah untuk meningkatkan kemampuan berbicara siswa dengan menerapkan metode sosiodrama melalui pembelajaran bahasa Indonesia di kelas V SD Negeri 104214 Deli Tua. Jenis penelitian ini adalah penelitian tindakan kelas (PTK) kolaboratif. Metode pengumpulan data yang digunakan adalah observasi, dan dokumentasi. Berdasarkan hasil observasi kemampuan awal peneliti bersama guru kelas 38 orang dari 26 orang siswa terdapat 5 siswa yang mampu berbicara dengan persentase $(13,1 \%)$ dan 33 siswa yang belum mampu berbicara dengan persentase $(86,9 \%)$, dengan nilai rata-rata kelas 23,68.
\end{abstract}

Kata Kunci: Kemampuan, Berbicara, Sosiodrama

\section{PENDAHULUAN}

Potensi yang ada pada diri setiap individu, masyarakat, bangsa dan negara merupakan hal penting yang harus dikembangkan. Pengembangan potensi di masyarakat, bangsa dan negara diawali dengan pengembangan potensi pada setiap individu. Untuk mengembangkan potensi yang ada di dalam setiap individu dibutuhkan sebuah sistem yang mampu mempersatukan setiap individu tersebut. Dalam sistem inilah setiap individu saling bertukar pendapat, gagasan, persaan, dan keinginan. Sistem tersebut merupakan sebuah kegiatan sosial yang disebut komunikasi atau berbicara yang merupakan kegiatan yang sangat diperlukan oleh setiap individu untuk mengembangkan potensinya.

Berbicara merupakan salah satu dari empat aspek keterampilan

Dosen Prodi PGSD Universitas Negeri Medan 
pada pembelajaran bahasa Indonesia.

Keempat aspek tersebut ialah aspek keterampilan menyimak, berbicara, membaca, dan menulis. Setiap aspek keterampilan itu erat sekali hubungannya dengan ketiga aspek lainnya dengan cara yang beranekaragam. Selanjutnya setiap keterampilan itu erat pula berhubungan dengan proses-proses berpikir yang mendasari bahasa. Bahasa seseorang mencerminkan pikirannya. Bahasa merupakan alat komunikasi dan alat berpikir yang menjadi titik penting dalam sebuah kesuksesaan. Semakin terampil seseorang berbahasa, semakin jelas pula jalan pikirannya.

Keterampilan berbahasa dapat diperoleh dan dikuasai dengan jalan praktek dan banyak latihan. Melatih keterampilan berbahasa berarti pula melatih keterampilan berpikir. Pentingnya fungsi bahasa terlihat pada pelajaran Bahasa Indonesia yang diberikan mulai dari pendidikan dasar sampai perguruan tinggi. Mulai dari pendidikan Bahasa Indonesia di sekolah dasar, siswa telah dilatih untuk mengembangkan keterampilannya berbahasa dan juga dalam konteks berkomunikasi atau berbicara.

Berdasarkan pengamatan yang dilakukan oleh peneliti di SD Negeri 104214 Deli Tua pada siswa kelas V, yaitu ketika peneliti mengajarkan pelajaran Bahasa Indonesia dengan materi menyampaikan gagasan dari sebuah karangan yang ditulisnya, siswa mengalami kesulitan dalam menyampaikan gagasan dari karangannya. Rendahnya kemampuan berbicara siswa sangat terlihat dalam proses pembelajaran. Peneliti melihat dari 38 siswa yang di beri intruksi untuk menyampaikan gagasan dari sebuah karangan, hanya ada 9 siswa $(23,68 \%)$ yang berani dan mampu menyampaikannnya dengan tepat dan benar. Hal ini tentunya kurang memuaskan karena mengingat Bahasa Indonesia adalah bahasa resmi yang harus dimengerti dan dikuasai oleh setiap siswa. Selain itu guru masih menggunakan metode konvensional sehingga pengasahan akan kemampuan berbicara pada siswa menjadi kurang maksimal.

Keadaan inilah yang mendorong peneliti untuk melakukan penelitian tindakan kelas di kelas V SD Negeri 104214 Deli Tua pada tahun 2016-2017, untuk mengatasi kesulitan guru dalam membelajarkan siswa agar mempunyai kemampuan berbicara dan berani mengungkapkan pendapatnya serta dapat berkomunikasi dengan baik dan benar. Penggunaan metode yang tepat dalam suatu pembelajaran dapat mendorong keberhasilan guru dalam proses belajar-mengajar sehingga apa yang ingin dicapai dari hasil pembelajaran akan maksimal dalam konsep dan makna pembelajaran.

Untuk meningkatkan kemampuan berbicara pada proses pembelajaran Bahasa Indonesia, tidak 
cukup dengan hanya menggunakan metode ceramah saja. Oleh sebab itu diperlukan metode yang lain. Metode yang dapat menstimulasi siswa untuk menjadi aktif dan memiliki keberanian untuk mengungkapkan gagasan ataupun perasaannya. Metode yang mampu menyesuaikan dengan kemampuan berbicara siswa, siswa harus mengalami sendiri menggunakan Bahasa Indonesia yang baik dan benar untuk membiasakan siswa terampil berbicara dan melafalkan. Salah satu metode yang bisa digunakan untuk mengasah kemampuan berbicara siswa adalah metode sosiodrama.

Pada tahun 2013 telah dilakukan penelitian oleh Akhyar Varianda terhadap siswa kelas V SD Negeri 101780 Percut Pada Mata Pelajaran Bahasa Indonesia. Tindakan pembelajaran yang digunakan adalah startegi sosiodrama. Jenis penelitan yang digunakan adalah penelitian tindakan kelas (PTK), dimana berjumlah 30 orang siswa. berdasarkan hasil penelitian tersebut melalui strategi sosiodrama dapat meningkatkan kemampuan berbicara siswa, dimana kemampuan berbicara siswa terus meningkat yang dapat di lihat dari tes siklus I pertemuan 1 yaitu terdapat 7 orang siswa yang memperoleh kriteria mampu $(23,33 \%)$, lalu pada pertemuan 2 siswa yang termasuk kriteria sangat mampu meningkat sekitar 3,33\%. Pada siklus II pertemuan 1 siswa yang dalam kriteria Mampu berjumlah 16 orang atau $53,33 \%$. selanjutnya pada pertemuan ke 2 siklus II siswa yang termasuk dalam kriteria sangat mampu berjumlah 12 orang siswa $(60,00 \%)$ dan yang termasuk dalam kriteria mampu berjumlah 18 orang siswa $(40,00 \%)$.

Berbicara merupakan suatu cara yang dibutuhkan sebagai alat pertukaran informasi dalam kehidupan. Berbicara secara umum dapat diartikan sebagai suatu penyampaian maksud (ide, pikiran, perasaan) seseorang kepada orang lain dengan menggunakan bahsa lisan sehingga maksud tersebut dapat dipahami oleh orang lain. Melatih kemampuan berbicara pada anak mulai di ajaarkan di usia sekolah dasar dalam mata pelajaran Bahasa Indonesia. Namun pada kenyataan yang ada di lapangan kemampuan berbicara siswa usia sekolah dasar belum optimal. Siswa masih sulit untuk menyampaikan ide, pikiran, dan perasaanya kepada guru dan teman-temannya, sulit untuk menyusun kata yang ada di dalam pikirannya menjadi kalimat yang baik dan benar.

Metode belajar sosiodrama dapat melatih kemampuan berbahasa anak sehingga bisa meningkatkan dan mengembangan kemampuan anak agar anak mampu berbahasa serta berkomunikasi dengan baik dan benar untuk mencapai kesuksesan dirinya melalui pelakonan tingkah laku yang menyenangkan dan dapat menciptakan motivasi. Metode 
sosiodrama memberi kemudahan kepada siswa untuk melatih kemampuan berbicara dan membantu guru dalam proses pembelajaran.

Agar pembelajaran dapat berjalan dengan optimal, guru harus kreatif dan mampu membangkitkan dan meningkatkan semangat siswa agar tercipta suasana yang diinginkan. Dengan menggunakan metode sosiodrama anak dapat termotivasi untuk meningkatkan kemampuan berbicaranya, dan pembelajaran menjadi lebih bervariasi.

Dari penjelasan di atas, penggunaan metode sosiodrama memperlihatkan banyak kebaikan, sehingga dapat diduga bahwa pengajarannya yang menggunakan metode sosiodrama dapat meningkatkan kemampuan berbicara siswa.

\section{METODE PENELITIAN}

Jenis peneltian ini adalah Penelitian Tindakan Kelas (PTK). Sesuai dengan jenis penelitiannya maka peneliti melakukan tahap-tahap penelitian yang berupa siklus. Poses dalam penelitian ini di harapkan terdiri dari dua siklus, tiap siklus dilaksanakan sesuai dengan perubahan yang akan dicapai.

Subjek penelitian ini adalah, siswa kelas V SD Negeri 104214 Deli Tua yang berjumlah 38 orang dengan jumlah siswa laki-laki 16 orang dan perempuan 22 orang.

Objek penelitian ini adalah Meningkatkan Kemampuan Berbicara
Siswa Dengan Menggunakan Metode Sosiodrama Pada Pelajaran Bahasa Indonesia pada Siswa Kelas V SD Negeri 104214 Deli Tua.

Penelitian ini menggunakan desain model Kemmis dan Mc Taggart dalam Romala (2014:66). Di dalam proses penelitiannya, peneliti menggunakan penelitian kolaboratif dimana dalam prosesnya peneliti bekerjasama dengan seorang guru kelas dan salah seorang teman. Dalam rosmala Dewi (2014:76) Kemmis dan Mc Taggart mengemukakan ada empat komponen pada desain, yaitu rencana, tindakan, observasi dan refleksi.

Sesuai dengan jenis penelitian ini, yaitu Peneltian Tindakan Kelas maka penelitian ini melalui dua siklus dimana setiap siklus mempunyai empat tahap seperti siklus yang telah digambarkan sebelumnya, yaitu perencanaan, tindakan, pemantauan, dan refleksi. Dalam setiap siklus ada 2 kali pertemuan sehingga dari 2 siklus ada 4 kali pertemuan, setiap siklus dilaksanakan seusai dengan perubahan yang ingin dicapai.

\section{Kisi-Kisi Penilaian Kemampuan Berbicara Siswa}

\begin{tabular}{|c|c|c|}
\hline No & $\begin{array}{c}\text { Aspek yang } \\
\text { Dinilai }\end{array}$ & Deskriptor Penilaian \\
\hline \multicolumn{3}{|c|}{ A. Kebahasaan } \\
\hline & Bunyi Bahasa & $\begin{array}{l}\text { Pengucapan bunyi bahasa } \\
\text { sudah tepat, jelas, mudah } \\
\text { dipahami, dan keefektifan } \\
\text { komunikasi yang sangat } \\
\text { baik. }\end{array}$ \\
\hline
\end{tabular}




\begin{tabular}{|l|l|l|}
\hline & Intonasi & $\begin{array}{l}\text { Penempatan tekanan, nada, } \\
\text { dan durasi sangat sesuai, } \\
\text { serta pembicaraan terlihat } \\
\text { menarik. }\end{array}$ \\
\hline B. & $\begin{array}{l}\text { Non- } \\
\text { Kebahasaan }\end{array}$ & $\begin{array}{l}\text { Berbicara dengan lancar, } \\
\text { tidak terlalu cepat, dan } \\
\text { tidak terputus-putus. }\end{array}$ \\
\hline & Kelancaran & $\begin{array}{l}\text { Pembicara menguasai } \\
\text { ketiga sikap (wajar, tenang, } \\
\text { tidak kaku) dengan baik }\end{array}$ \\
\hline Ketenangan & $\begin{array}{l}\text { Gerak gerik dan mimik } \\
\text { pembicara sangat tepat }\end{array}$ \\
\hline Nonverbal & $\begin{array}{l}\text { Topik } \\
\text { Pembicaraan }\end{array}$ & $\begin{array}{l}\text { Penguasaan topik } \\
\text { pembicaraan sangat baik. }\end{array}$ \\
\hline
\end{tabular}

Penelitian dilaksanakan di kelas V SD Negeri 104214 Deli Tua. Penelitian ini dilaksanakan selama 2 bulan mulai dari kegiatan persiapan sampai pelaksanaan tindakan.

\section{HASIL DAN PEMBAHASAN}

Penelitian ini dilakukan pada siswa kelas V SD Negeri 104214 Deli Tua. Jumlah siswa kelas V sebanyak 38 siswa yang terdiri dari 16 orang siswa laki-laki dan 22 orang siswa perempuan.

Langkah awal yang dilakukan oleh peneliti sebelum melakukan penelitian tindakan kelas yaitu mengamati pembelajaran kemampuan berbicara Bahasa Indonesia siswa kelas V SD Negeri 104214 Deli Tua. Dalam penelitian awal ini, guru bekerjasama dengan guru untuk mengetahui hasil awal kemampuan berbicara siswa. Langkah-langkah yang dilakukan guru dalam pembelajaran tersebut adalah dengan memberikan tugas kepada siswa untuk menulis deskripsi tentang kegemarannya. Kemudian siswa diminta untuk membacanya dalam hati. Setelah itu, satu per satu dari siswa maju ke depan mendeskripsikan diri siswa secara lisan tanpa membawa teks yang telah siswa buat sebelumnya.

Berdasarkan pengamatan tersebut, ditemukan permasalahan dalam pembelajaran Bahasa Indonesia khususnya dalam hal berbicara. Banyak siswa yang masih mengalami kesulitan dalam mengungkapkan pendapat ke dalam kalimat yang benar. Siswa cenderung malu dan kurang percaya diri karena belum terbiasa berbicara di depan umum. Siswa merasa takut salah dan minat siswa dalam pembelajaran keterampilan berbicara pun masih rendah.

Saat siswa tidak maju, siswa sibuk bercanda dan bermain sendiri. Siswa tidak memperhatikan apa yang disampaikan temannya yang sedang maju. Siswa merasa pembelajaran keterampilan berbicara kurang penting karena tidak ada di dalam ujian maupun ulangan. Sehingga pembelajaran keterampilan berbicara dianggap angin lalu oleh para siswa.

Berdasarkan hasil tabel tentang kondisi awal kemampuan berbicara siswa kelas V SD Negeri 104214 Deli Tua maka diperoleh ketuntasan klasikal yaitu:

$$
\begin{aligned}
& \mathrm{P}=\frac{f}{n} \times 100 \\
& \mathrm{P}=\frac{9}{38} \times 100 \\
& \mathrm{P}=23,68
\end{aligned}
$$


Persentase Kemampuan Berbicara Siswa Pada Kondisi Awal

\begin{tabular}{|l|c|c|c|l|}
\hline No. & Nilai & $\begin{array}{c}\text { Jumlah } \\
\text { Siswa }\end{array}$ & Persentase & Ket. \\
\hline 1 & 100 & - & - & $\begin{array}{l}\text { Sangat } \\
\text { Mampu }\end{array}$ \\
\hline 2 & 80 & 5 siswa & $13,1 \%$ & Mampu \\
\hline 3 & 69 & 4 siswa & $10,6 \%$ & $\begin{array}{l}\text { Cukup } \\
\text { Mampu }\end{array}$ \\
\hline 4 & $<59$ & 29 siswa & $76,3 \%$ & $\begin{array}{l}\text { Kurang } \\
\text { Mampu }\end{array}$ \\
\hline \multicolumn{2}{|c|}{ Jumlah } & 38 siswa & $100 \%$ & \\
\hline
\end{tabular}

Dari tabel di atas dapat dilhat bahwa hanya ada 5 orang siswa atau $13,1 \%$ yang dikategorikan mampu dan hanya ada 4 orang siswa atau $10,6 \%$ yang dikategorikan cukup mampu, sedangkan 29 orang siswa lainnya atau $76,3 \%$ termasuk dalam kategori kurang mampu. Hal ini menunjukkan rendahnya kemampuan berbicara pada siswa. Hasil observasi kemampuan berbicara siswa pada tes awal dapat digambarkan dalam diagram berikut ini.

\section{Diagram Perolehan Nilai}

\section{Kemampuan Berbicara Siswa pada Kondisi Awal}

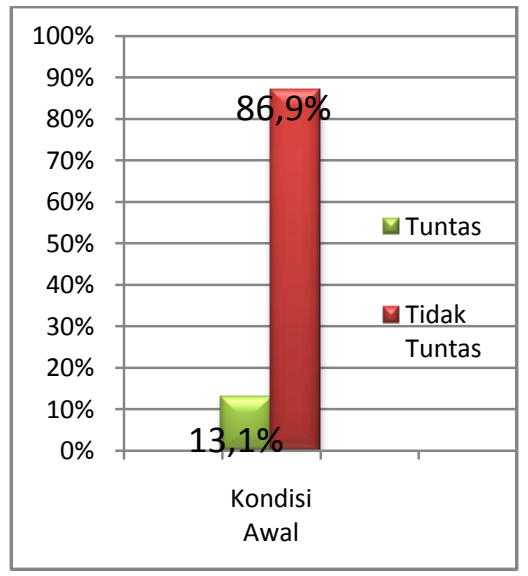

Berdasarkan hasil penelitian tindakan kelas yang dilakukan di kelas V SD Negeri 104214 Deli Tua pada pelajaran Bahasa Indonesia menunjukkan bahwa metode sosiodrama dapat meningkatkan kemampuan berbicara siswa. Pembelajaran keterampilan berbicara dengan menggunakan metode sosiodrama di siklus I dapat meningkatkan keterampilan berbicara siswa sebesar 13,3\%, (pertemuan pertama $23,6 \%$ menjadi $36,9 \%$ pada pertemuan kedua). Namun pelaksanaan pembelajaran pada siklus I belum berjalan dengan lancar karena masih ada beberapa kendala. Di antara kendala tersebut adalah siswa masih merasa takut, malu, dan kurang percaya diri untuk memerankan sosiodrama. Siswa belum terbiasa untuk tampil berbicara di muka umum.

Selain itu, kerja sama di antara anggota kelompok belum terbentuk, dan belum maksimalnya kesadaran siswa untuk menghafal naskah sosiodrama. Akibatnya pencapaian nilai yang diharapkan belum optimal. Pelaksanaan siklus I dilakukan selama dua kali pertemuan, diawali dengan melakukan apersepsi untuk mengarahkan siswa pada materi yang akan dipelajari, membentuk kelompok, mejelaskan tentang materi yang akan dipelajari selanjutnya menggali pemahaman siswa tentang pelajaran yang telah dipelajarinya.

Hasil pengamatan guru, peneliti dan rekan sejawat pada siklus 
II tampak bahwa kegiatan diawali dengan melakukan apersepsi untuk mengarahan siswa pada materi yang akan dipelajari, membebaskan siswa berekspresi dengan menulis drama untuk kelompok mereka sendiri pada pertemuan ke dua, kemudian guru mengumpulkan naskah drama yang sudah ditulis dan menceritakan inti dari persoalan pada drama yang telah ditulis lalu mensosiodramakannya sesuai dengan langkah-langkah penggunaan metode sosiodrama.

Secara keseluruhan pelaksanaan pembelajaran dalam siklus II telah mampu mengatasi kendala yang terjadi dalam siklus I sehingga proses pembelajaran mengalami kemajuan. Kemajuan tersebut di antaranya, siswa menjadi lebih berani dan lebih percaya diri untuk memerankan sosiodrama. Hal tersebut ditunjukkan saat siswa bermain sosiodrama, kenyaringan suara siswa menjadi lebih lantang. Siswa menjadi lebih terbiasa untuk tampil berbicara di muka umum.

Kerja sama di antara kelompok telah terbentuk karena di siklus II setiap anggota kelompok telah berkumpul di kelompoknya masing-masing. Siswa dapat menjadi lebih aktif dan antusias karena dapat berlatih bersama anggota kelompoknya secara lebih dekat. Respon siswa terhadap pertanyaanpertanyaan yang diberikan oleh guru menjadi lebih beragam. Kemampuan siswa dalam menghafal naskah sosiodrama menjadi lebih baik.
Sehingga dalam memainkan sosiodrama siswa lebih terlihat dapat menguasai jalannya cerita. Sikap siswa menjadi lebih baik selama pembelajaran kemampuan berbicara menggunakan metode sosiodrama. Siswa menjadi lebih semangat dalam mengikuti pembelajaran. Optimisme dalam diri siswa meningkat, rasa kebersamaan dengan teman semakin tumbuh, dan kesetiakawanan sosial menjadi tinggi.

Dengan sosiodrama, siswa dapat mengambil hikmah dari ceritacerita sosiodrama yang telah siswa perankan. Siswa belajar untuk lebih peduli dengan sesama, selalu bersikap jujur, mudah memaafkan, menghargai pendapat orang lain, dan banyak lagi yang dapat siswa petik dalam ceritacerita sosiodrama tersebut. Siswa belajar bertanggung jawab dengan peran yang siswa mainkan, belajar bagaimana mengambil keputusan dalam situasi kelompok, dan metode sosiodrama juga merangsang siswa untuk berpikir dan memecahkan suatu masalah yang sering terjadi di sekitar siswa.

Dari hasil pengamatan peneliti dan rekan sejawat, maka pada Kondisi awal, siklus I, dan siklus II kemampuan berbicara semua siswa kelas V SD Negeri 104214 tergolong dalam kategori tuntas. Dengan perolehan jumlah siswa yang tergolong dalam kategori tuntas secara klasikal adalah 38 siswa atau $100 \%$. 
Dengan demikian, berdasarkan hasil penelitian dan pengamatan peneliti yang dilakukan mulai dari pengamatan awal, kmeudian masuk pada pembelajaran siklus I dan yang terakhir adalah pelaksanaan siklus II, maka dapat dikatakan metode sosiodrama dapat dipandang sangat baik dalam menngkatkan kemampuan berbicara siswa pada pelajaran Bahasa Indonesia materi ajar memerankan tokoh drama melalui teks percakapan di kelas V SD Negeri 104214 Deli Tua.

\section{SIMPULAN}

Berdasarkan hasil analisis data, dapat disimpulkan bahwa pembelajaran keterampilan berbicara menggunakan metode sosiodrama yang dilaksanakan secara berkala dapat ditarik kesimpulan sebagai berikut:

1. Dengan menggunakan metode sosiodrama, kemampuan berbicara siswa kelas V SD Negeri 104214 mengalami peningkatan.

2. Pada pelaksanaan tindakan di siklus I terjadi peningkatan kemampuan berbicara siswa. Kemampuan berbicara siswa meningkat sebesar 13,3\%, dari pertemuan pertama 23,6 \% menjadi $36,9 \%$ pada pertemuan kedua.

3. Pada tahap tindakan selanjutnya yaitu pelaksanaan pada siklus II, terjadi peningkatan yaitu dari 38 siswa tampak ada sebagian siswa yang mencapai tingkat kemampuan berbicara sangat mampu yakni 20 orang atau 52,6\% kemudian 18 siswa atau 47,3\%, yang mencapai kriteria mampu. Maka dapat terlihat jelas peningkatan yang dialami oleh siswa dan peneliti menyimpulkan penelitian ini dicukupkan hanya pada siklus II pertemuan 2 .

Berdasarkan penelitian yang telah dilakukan, peneliti memberikan beberapa saran yang perlu dipertimbangkan oleh berbagai pihak berkaitan dengan pelaksanaan pembelajaran keterampilan berbicara dengan menggunakan metode sosiodrama sebagai upaya meningkatkan kemampuan berbicara siswa kelas V SD Negeri 104214 Deli Tua:

1. Kepada siswa, dalam upayanya meningkatkan kemampuan berbicara, disarankan agar lebih sering bermain sosiodrama bersama teman-temannya dan lebih aktif dalam proses pembelajarannya.

2. Kepada guru kelas, penelitian ini membuktikan bahwa metode sosiodrama dapat meningkatkan keterampilan berbicara siswa, sehingga diharapkan metode sosiodrama dijadikan alternatif penerapan metode pembelajaran dalam mata pelajaran Bahasa Indonesia, khusunya pada kemampuan berbicara. 
3. Kepada pihak sekolah, penelitian ini dapat dijadikan sebagai bahan pertimbangan sekolah dalam rangka pembinaan guru-guru kelas untuk menggunakan metode sosiodrama dalam upaya meningkatkan keterampilan berbicara siswa.

4. Bagi peneliti lain, dapat melakukan penelitian yang sejenis pada materi dan sekolah yang lainnya, agar dapat diperoleh hasl yang maksimal sehingga hasil penelitian ini bermanfaat sebagai riset teori maupun sebagai acuan terhadap proses pembelajaran di kelas.

\section{DAFTAR RUJUKAN}

Dewi, Rosmala. 2015. Peneltian Tindakan Kelas. Medan: UNIMED Press.

Haryadi \& Zamami. 1997. Peningkatn Keterampilan Bahasa. Yogyakarta: Depdikbud.

Istarani. 2002. Kumpulan 39 Metode Pembelajaran. Medan: Isco Medan.

Juanda, Reza. 2014. Penggunaan Metode Bermain Peran Untuk Meningkatkan Kemampuan berwawancara Dengan Berbagai Kalangan. 15-16.

Kurniasih, Imas \& Sani, Berlin. 2015. Ragam Pengembangan Pembelajaran. Jakarta: Kata Pena.

Robbins, Stephen P. \& Judge, Timothy A. 2008. Perilaku
Organisasi. Jakarta: Salemba Empat.

Roestiyah. 2008. Strategi Belajar Mengajar. Jakarta: Rineka Cipta.

Rosmawaty. 2011. Seni Drama, Medan: UNIMED.

Sabarati Akhada, dkk. 1997. Bahasa Indonesia I, Jakarta: Depdikbud.

Sula, S.L.La \& Tirtarahardjo, Umar. 2005. Pengantar Pendidikan, Jakarta: Rineka Cipta.

Susetyo, Budi. 2015. Prosedur Penyusunan dan Analisis Tes. Bandung: Refika Aditama.

Tarigan, Henry Guntur. 2007. Berbicara Sebagai Suatu Keterampilan Berbahasa, Bandung: Angkasa.

UU RI No. 20. 2003. Sistem Pendidikan Nasional. 